\title{
Distribution of gall-inducing arthropods in areas of deciduous seasonal forest of Parque da Sapucaia (Montes Claros, MG, Brazil): effects of anthropization, vegetation structure and seasonality
}

\author{
Kelly Christie dos Santos Costa ${ }^{1,2}$ \& Walter Santos de Araújo $0^{1,3}$ \\ 1 Universidade Estadual de Montes Claros (UNIMONTES), Centro de Ciências Biológicas e da Saúde (CCBS), \\ Departamento de Biologia Geral. Montes Claros, MG, Brasil. \\ ${ }^{2}$ http://orcid.org/0000-0001-6156-0720.E-mail: kel_christie@hotmail.com \\ 3 http://orcid.org/0000-0003-0157-6151.E-mail:walterbioaraujo@yahoo.com.br
}

\begin{abstract}
In the present study, we inventoried gall-inducing arthropod species and evaluated the effects of habitat anthropization, vegetation structure and seasonality on this group in areas of deciduous seasonal forest of Parque da Sapucaia, Montes Claros, MG, Brazil. The gall-inducing fauna was sampled between April 2017 and February 2018 from 20 plots distributed in anthropized and preserved habitats. A total of 29 morphospecies of gall-inducing arthropods and 21 species of host plants were recorded. The Fabaceae plant family had the highest number of gall morphospecies $(n=10)$, while the Cecidomyiidae (Diptera) insect family induced the most galls (41.3\%). Mean gall richness did not differ between preserved and anthropized plots, but was negatively affected by mean vegetation height and density. The total number of gall morphospecies recorded during each sampling did not differ between dry and rainy seasons, but the mean richness of galls per plot was higher in the rainy season. In conclusion, natural factors, such as vegetation structure and seasonality, were more important for the distribution of gall-inducing species than anthropic factors, such as vegetation anthropization level.
\end{abstract}

Keywords. Cecidomyiidae; Fabaceae; Galls; Seasonal deciduous forest; Habitat modification.

\section{INTRODUCTION}

Galls are vegetative structures formed as the result of cellular modifications to plant tissues induced by different organisms, such as gall-inducing insects and mites (Shorthouse \& Rohfritsch, 1992). Gall-inducing arthropods are considered the most sophisticated phytophagous insects in nature (Shorthouse et al., 2005), since they are the only ones able to manipulate vegetal tissues to obtain food and shelter from environmental conditions and natural enemies (Stone \& Schönrogge, 2003). Gall-inducing arthropods are abundant in warm, dry habitats, and especially on sclerophyllous plants in tropical and temperate regions (Price et al., 1998). In addition to their enormous diversity, there is evidence that these arthropods' galls can be used as indicators of habitat quality (Fernandes et al., 1995; Toma et al., 2014), since their occurrence responds to environmental and anthropic modifications (Araújo et al., 2011a; Araújo \& Espírito-Santo Filho, 2012; Brito et al., 2018). In this sense, since gall-inducing species tend to preferentially occur in either natural or anthropically-stressed habitats (Araújo \& Espírito-Santo Filho, 2012), their galls can be used as potential indicators of environmental quality in vegetation near urban centers.

The vegetation's structural complexity can also be an important factor for the distribution of gall-inducing arthropods (Fleck \& Fonseca, 2007; Araújo et al., 2013). Its density, for example, may be an indicator of the host plants' nutritional quality, which tends to increase the richness of gall-inducing species (Cuevas-Reyes et al., 2004). There is also evidence that the host plant's height is strongly related to the abundance of the associated gall-inducing arthropods (Fleck \& Fonseca, 2007; Araújo \& Santos, 2009), because taller plants have greater biomass and, consequently, greater availability of resources (e.g., food and oviposition sites) for these species (Araújo et al., 2006). Therefore, environments with greater structural complexity tend to harbor more species of gall-inducing arthropods (Araújo et al., 2013; Cuevas-Reyes et al., 2004). 
Gall-inducing arthropods have been studied in several types of ecosystems in Brazil, including humid tropical forests (e.g., Almada \& Fernandes, 2011; Araújo \& EspíritoSanto Filho, 2012; Fernandes et al., 2009; Julião et al., 2005), Restingas (e.g., Mendonça et al., 2010; Rodrigues et al., 2014) and savannas (e.g., Araújo \& Guilherme, 2012; Araújo et al., 2014). On the other hand, relatively little research has been done on gall-inducing arthropods in deciduous seasonal forests in Brazil (e.g., Coelho et al., 2009; Goetz et al., 2018; Santos et al., 2011). Due to the seasonal change of vegetation in these forests, with high deciduousness during the dry season, the composition of the herbivorous insect fauna is quite variable, with their abundance increasing during the rainy season (Filip et al., 1995). Cuevas-Reyes et al. (2006) propose that the synchronization between gall formation and early leaf histogenesis in the wet season is more likely in strongly seasonal vegetation. Gall-inducing arthropods may be adapted to follow the phenological patterns of their host plant species in these environments, which makes them an interesting object for studying how these synchronous patterns are regulated.

The objective of the present study was to inventory the diversity of arthropod galls in different areas of deciduous seasonal forest in Parque da Sapucaia, Montes Claros, Minas Gerais, Brazil. Furthermore, the effects of anthropization (anthropic vs. preserved), season (dry vs. rainy) and vegetation structure (density and height) on the richness of gall-inducing arthropods were evaluated. The following hypotheses were assessed: (I) there is greater richness of gall-inducing arthropods in anthropized environments than in preserved environments, because these species tend to be benefited by anthropically-stressed habitats (Araújo et al., 2011a; Araújo \& Espírito-Santo Filho, 2012); (II) there is greater richness of gall-inducing arthropods during the rainy season than during the dry season, due to the greater availability of leaves for oviposition (Filip et al., 1995); and (III) the richness of gall-inducing arthropods is positively correlated with the vegetation's height and density, since they represent a greater availability of resources for these insects (Araújo et al., 2013; Cuevas-Reyes et al., 2004).

\section{MATERIAL AND METHODS}

\section{Study area}

The study was performed in a local conservation unit, Parque da Sapucaia, $\left(16^{\circ} 44^{\prime} 32^{\prime \prime} S, 43^{\circ} 54^{\prime} 03^{\prime \prime} \mathrm{W}\right)$ in the municipality of Montes Claros, northern region of the state of Minas Gerais, Brazil. The park is situated between the urban zone of the city of Montes Claros and Parque Estadual da Lapa Grande, which is a major conservation unit in the city (Fig. 1a). Parque da Sapucaia comprises an area of approximately 30.2 hectares in the western region of the city that is popularly known as Serra do Sapucaia or Serra do Mel. The elevation of the park ranges from 690 to $872 \mathrm{~m}$, and the climate of the region is tropical semi-arid, according to the Köppen classification, with hot summers and dry winters and an annual average temperature of $24.1^{\circ} \mathrm{C}$ (Alvares et al., 2013; Santos et al., 2007). The vegetation is predominantly composed of seasonal deciduous forest, also known as tropical dry forest (Santos \& Vieira, 2006; Santos et al., 2007). This vegetation has a closed canopy during the rainy season (Fig. 1b) and high deciduousness, with more than 50\% of the leaves being lost during the dry season (Fig. 1c) (Santos et al., 2007).

\section{Sampling of host plants and gall-inducing arthropods}

All plants with a circumference equal to or greater than $15 \mathrm{~cm}$ (measured $1.5 \mathrm{~m}$ above ground) were sampled in twenty $10 \times 10 \mathrm{~m}$ plots in the areas of deciduous seasonal forest (method described by Araújo \& Guilherme, 2012; Araújo et al., 2013; Araújo et al., 2014). From this total, we allocated 10 plots in areas with anthropized vegetation and 10 plots in areas with preserved vegetation. The anthropized areas were identified based on signs of human intervention, such as selective vegetation cutting and the presence of buildings (e.g., paved trails, cable car and kiosks) and garbage deposits. On the other hand, the preserved vegetation areas were characterized by pristine vegetation, with no detectable evidence of human intervention. All sampled plants were identified and marked with colored ribbons. The botanical material was herborized and identified according to the botanical literature and/or the recommendation of experts. The vegetation's height and density were quantified for each sampling plot. The plants' height was always visually estimated by the same sampler, while density was calculated from the number of trees recorded in the plot.

Gall sampling was performed during six field campaigns: three during the dry season (April 2017, June 2017 and August 2017) and three during the rainy season (September 2017, December 2017 and February 2018). For each sampling, all host plants in the plots were inspected by active searches for galls up to a height of 2.5 meters. All galls found were registered and classified according to morphotype using the host plant's species and the gall's external morphology (plant organ, shape, color, pubescence and size; see Isaias et al., 2013). A representative of each gall morphotype was photographed, collected, individually transported in a labeled plastic bag, and sent to the Laboratory of Interactions, Ecology and Biodiversity (LIEB) of Universidade Estadual de Montes Claros (UNIMONTES). To obtain the gall-inducing arthropods, each gall was placed in a plastic container with moistened paper towel. The arthropods were identified after the emergence of adults or after the galls' dissection to obtain immature samples.

\section{Data analyses}

For the statistical analyses, gall morphotype richness was considered the response variable and habitat type 
(anthropized vs. preserved), vegetation structure (density and height), and seasonality (dry period vs. rainy season) the explanatory variables. The effect of habitat type (anthropized vs. preserved) and vegetation structure on gall morphotype richness was tested in the analysis of covariance (ANCOVA). The total and mean richness of gall morphotypes per plot were compared between the two seasons using the $t$-test for independent factors,
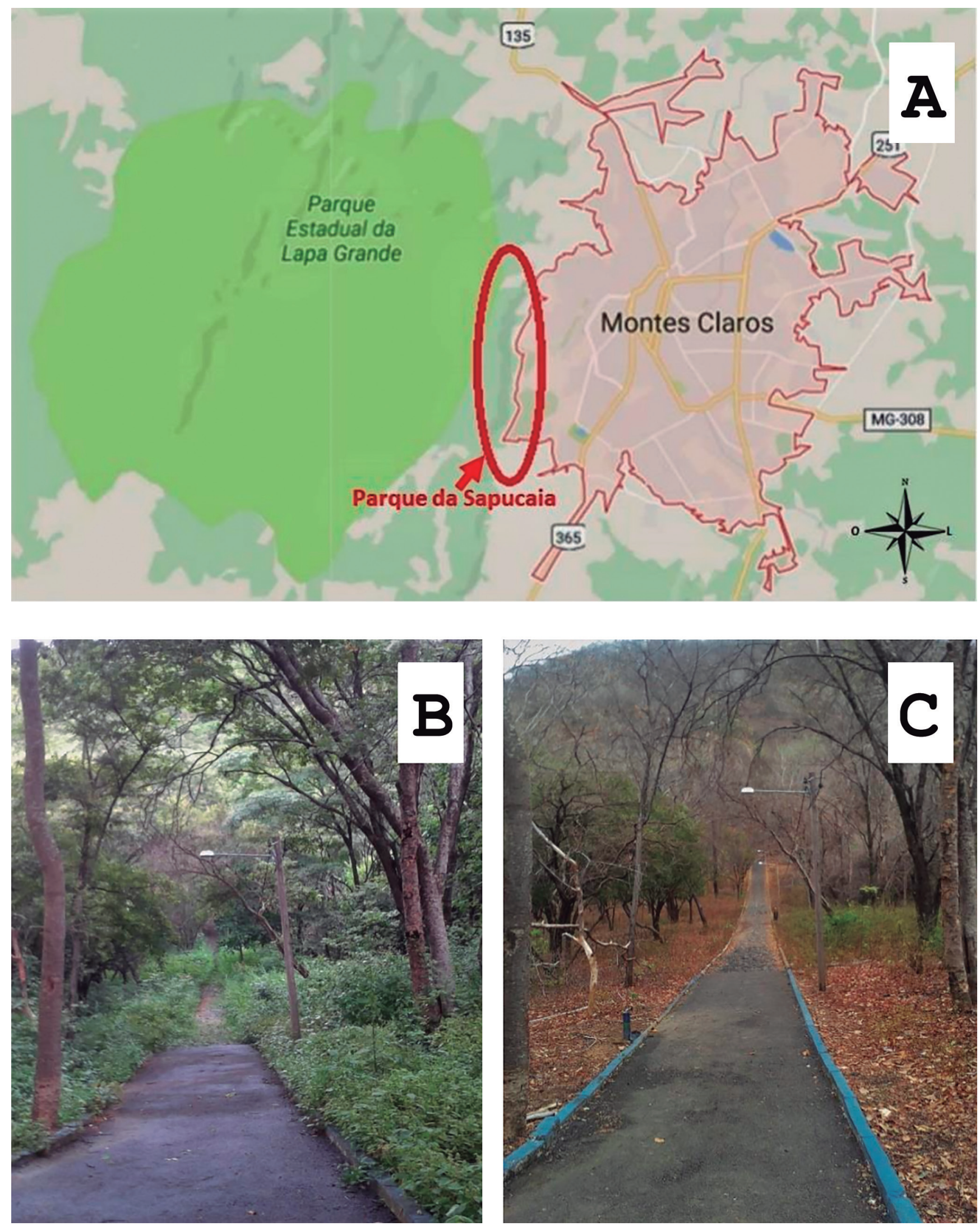

Figure 1. Location and characterization of the study area. (A) Location of Parque da Sapucaia (Montes Claros, MG, Brazil), between the urban area of Montes Claros and Parque Estadual da Lapa Grande. Source: Google Earth. (B) Characterization of the vegetation in the rainy season. (C) Characterization of the vegetation in the dry season. 
while mean gall morphotype richness was compared between preserved and anthropized plots and between seasons using the analysis of variance (ANOVA). In addition, we also used $t$-tests to test whether the total richness and each host plant species' richness differ between
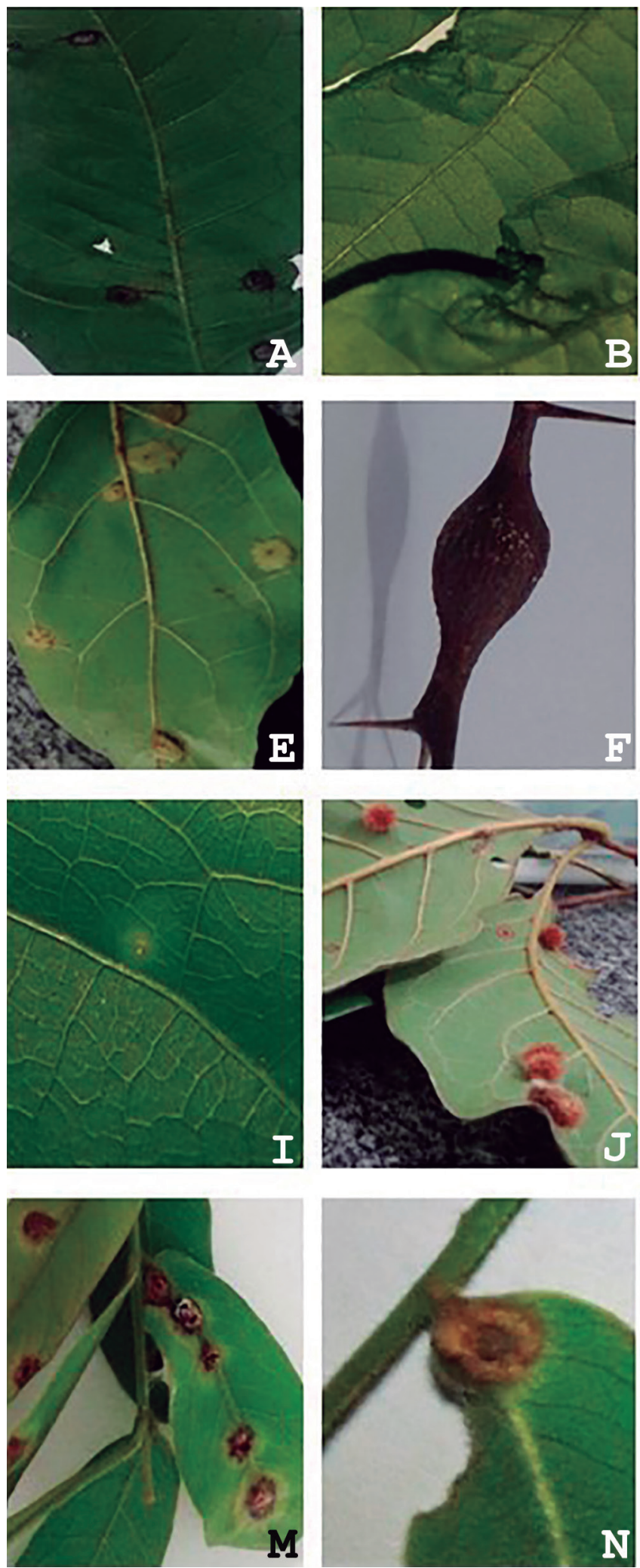

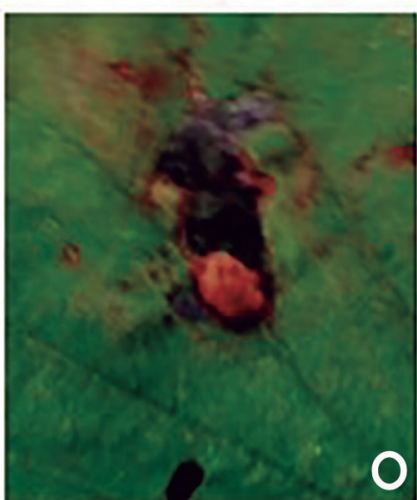

the preserved and anthropogenic plots. Assumptions of normality and homogeneity were verified prior to all analyses.

Multivariate analyses were used to test for differences in the composition of the host plants and gall-inducing ar-
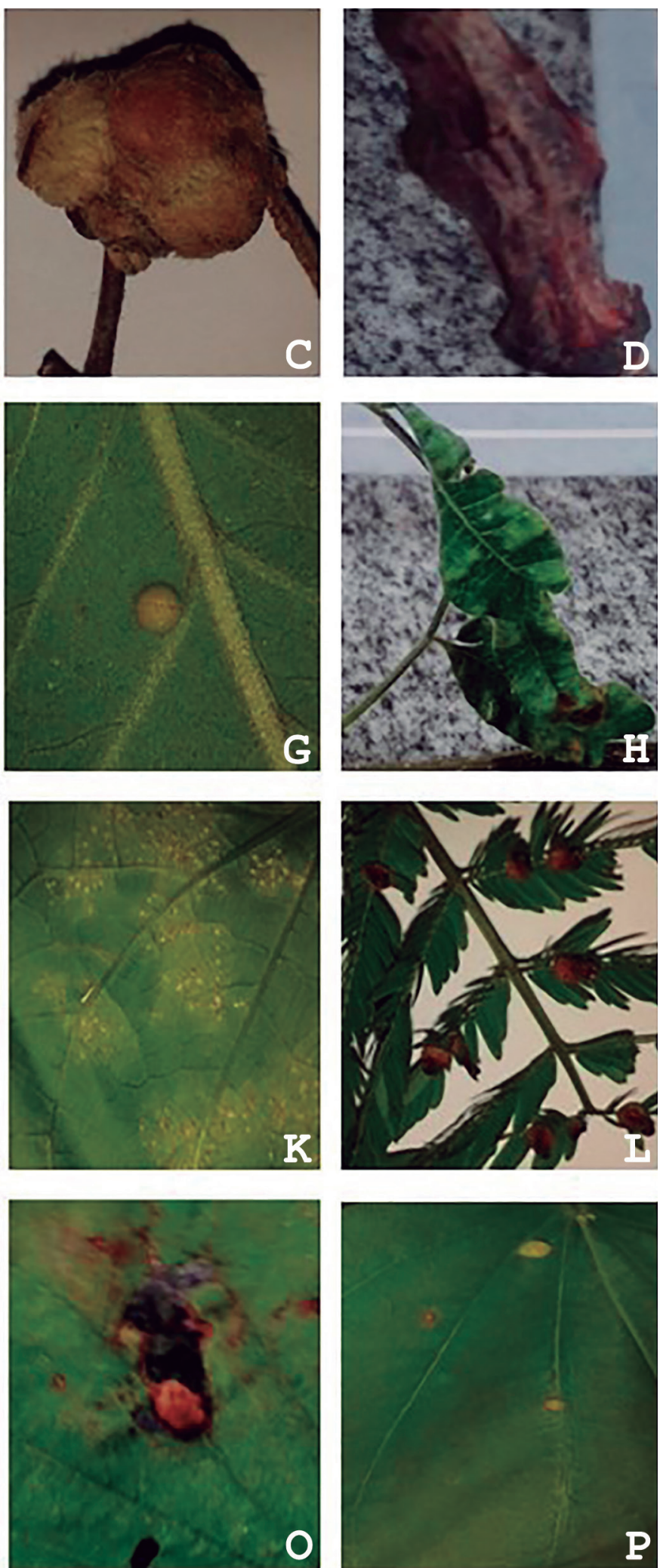

Figure 2. Morphological characterization of the galls induced by arthropods in areas of deciduous seasonal forest of Parque da Sapucaia (Montes Claros, MG, Brazil): (A) Anacardiaceae - Myracrodruon urundeuva; (B) Schinopsis brasiliensis; (C, D) Asteraceae - Vernonanthura brasiliana; (E) Bignoniaceae undetermined; (F, G) Cannabaceae - Celtis brasiliensis; (H) Combretaceae - Combretum leprosum; (I) Combretum duarteanum; (J) Terminalia phaeocarpa; (K) Cucurbitaceae undetermined; (L) Fabaceae - Anadenanthera colubrine; (M, N) Apuleia leiocarpa; (0) Bauhinia pulchela; and (P) Bauhinia rufa. 
thropods between the anthropized and preserved plots. Firstly, Non-metric Multidimensional Scaling (nMDS) was used to order the samples based on the Jaccard similarity index. Subsequently, a non-parametric permutation procedure (ANOSIM) was applied with 1,000 permutations, also based on the Jaccard index, to test the significance of the groups formed in the nMDS (Hammer et al., 2001). The values of $p$ and $r$ were obtained and the similarity patterns between the gall-inducing arthropod species in the studied plots were determined.

\section{RESULTS}

A total of 29 morphotypes of gall-inducing arthropods were found distributed among 21 species of host plants belonging to 13 botanical families (Table 1; Figs. 2-3). The most frequently encountered gall-induc- ing arthropod group was Cecidomyiidae (Diptera), which induced $12(41.3 \%)$ gall morphotypes. In addition, six (20.6\%) gall morphotypes induced by mites (Acari) were found, and one (3.4\%) induced by Psyllidae (Hemiptera). It was not possible to determine the inducer taxon for nine (34.4\%) of the morphotypes because the galls were collected without their inhabitants or the branch was resected before the emergence of adults.

The plant families with the greatest richness of gall morphotypes were Fabaceae, with ten morphotypes each; Combretaceae and Loganiaceae, with three morphotypes each (Table 1); Anacardiaceae, Asteraceae and Cannabaceae, with two morphotypes each; and Bignoniaceae, Cucurbitaceae, Sapindaceae, Opiliaceae, Vitaceae and Sapindaceae, with a single morphotype each. Two host plants were not identified in relation to family or species level (one morphotype each). The host plant genera with the greatest number of morphotypes
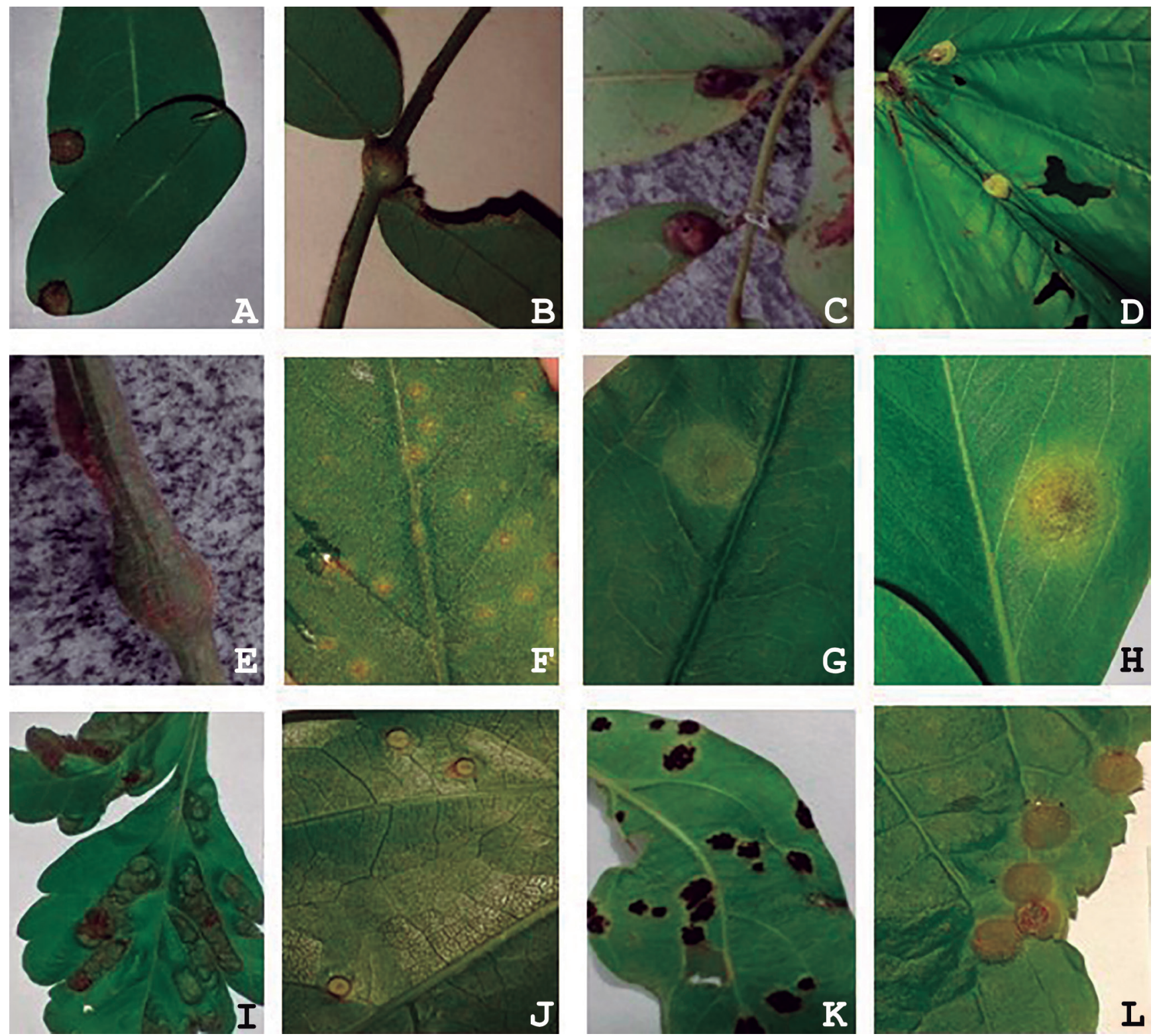

Figure 3. Morphological characterization of the galls induced by arthropods in areas of deciduous seasonal forest of Parque da Sapucaia, Montes Claros, MG, Brazil: (A, B, C) Fabaceae - Dalbergia sp.; (D) undetermined; (E, F, G) Loganiaceae - Sthrychnos sp.; (H) Opiliaceae - Agonandra brasiliensis; (I) Sapindaceae - Serjania sp.; (J) Vitaceae - Cissus sp.; (K) Undetermined family 1; and (L) Undetermined family 2. 
Table 1. Number of gall-inducing arthropod morphotypes and host plant species in the different families recorded in the preserved and anthropogenic areas of deciduous seasonal forest of Parque da Sapucaia (Montes Claros, MG, Brazil).

\begin{tabular}{lcccccc}
\hline \multirow{2}{*}{ Host plant family } & \multicolumn{3}{c}{ Richness of host plants } & \multicolumn{3}{c}{ Richness of gall morphotypes } \\
\cline { 2 - 7 } & Anthropized Preserved & Total & Anthropized Preserved & Total \\
\hline Anacardiaceae & 1 & 1 & 2 & 1 & 1 & 2 \\
Asteraceae & 0 & 1 & 1 & 0 & 2 & 2 \\
Bignoniaceae & 0 & 1 & 1 & 0 & 1 & 1 \\
Cannabaceae & 1 & 1 & 1 & 1 & 2 & 2 \\
Combretaceae & 0 & 3 & 3 & 0 & 3 & 3 \\
Cucurbitaceae & 0 & 1 & 1 & 0 & 1 & 1 \\
Fabaceae & 4 & 5 & 6 & 5 & 8 & 10 \\
Loganiaceae & 1 & 1 & 1 & 2 & 2 & 3 \\
Opiliaceae & 1 & 0 & 1 & 1 & 0 & 1 \\
Sapindaceae & 1 & 1 & 1 & 1 & 1 & 1 \\
Vitaceae & 0 & 1 & 1 & 0 & 1 & 1 \\
Undetermined family & 0 & 1 & 1 & 1 & 1 & 1 \\
Undetermined family 2 & 1 & 0 & 1 & 0 & 1 & 1 \\
\hline \multicolumn{1}{c}{ Total } & 9 & 16 & 21 & 12 & 24 & 29
\end{tabular}

were Dalbergia (Fabaceae) and Strychnos (Loganiaceae), with three morphotypes each (Table 1). Of the 21 plant species recorded, 15 species occurred in the preserved plots and 10 species were registered in the anthropized plots. The mean plant species richness per plot did not differ between the anthropic and preserved plots, both considering all plant species $(t=-0.70, p>0.05)$ and only the host plant species $(t=1.46, p>0.05)$. Similarly, the plant species' composition did not differ between the anthropized and preserved areas (ANOSIM: Stress < 0.01; $r=0.054, p>0.05$ ).

Most of the morphotypes had an undefined shape $(27.5 \%)$, followed by those with globoid (20.6\%), discoid (13.7\%), ellipsoid (10.3\%), cylindrical (6.8\%) and conical (3.4\%) shapes. All the galls occurred in isolation, and $82.7 \%$ did not exhibit pilosity. The most affected organ of the host plants was the leaf $(82.2 \%)$, followed by the branch (17.8\%) (Table 2). The most frequent gall color was green $(44.8 \%)$, followed by brown (27.5\%). Since there are no previous data on the gall host plants of Parque da Sapucaia, the results presented here are new for this field of study.

More morphotypes were found in the preserved plots $(n=24)$ than in the anthropized plots $(n=12)$, but the mean gall morphotype richness $(\mathrm{F}=3.07, p>0.05)$ and the gall-inducing fauna's composition (ANOSIM: Stress $<0.001 ; r=0.052, p>0.05$ ) did not significantly differ between preserved and anthropized plots. However, gall richness was significantly affected by the vegetation's mean height $(F=7.59, p=0.01)$ and density $(F=4.60, p=0.04)$. Contrary to expectations, the vegetation's mean height had a negative influence on gall morphotype richness in all plots (Fig. 4), while its density negatively affected the number of galls in the preserved plots only (Fig. 5). The total number of gall morphotypes recorded during each field campaign did not differ between the dry season and the rainy season ( $\mathrm{t}=-1.36, p>0.05)$, but there was greater mean morphotype richness per plot in the rainy season compared to

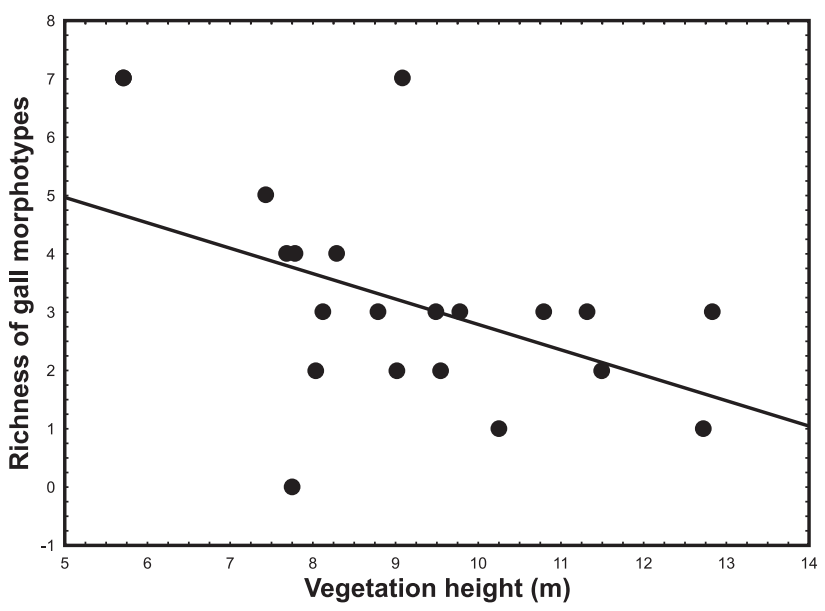

Figure 4. Relationship between the average height of the vegetation (m) and the richness of gall morphotypes in different plots of deciduous seasonal forest of Parque da Sapucaia (Montes Claros, MG, Brazil).

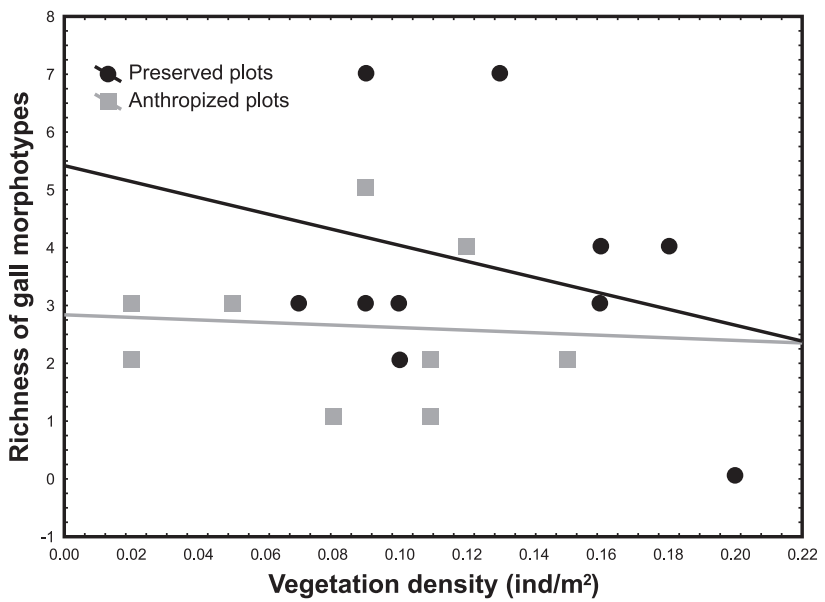

Figure 5. Relationship between vegetation density (ind $/ \mathrm{m}^{2}$ ) and the richness of gall morphotypes in different plots of deciduous seasonal forest of Parque da Sapucaia (Montes Claros, MG, Brazil).

the dry season ( $\mathrm{t}=-2.48, p=0.01$; Fig. $6 \mathrm{a}$ ). In addition, the mean number of gall morphotypes was higher in the preserved plots during the rainy season compared to the dry season, and in the anthropized plots, during either season ( $F=3.16, p=0.02$; Fig. $6 b)$.

\section{DISCUSSION}

This is the first study of arthropod-induced galls conducted in Parque da Sapucaia, Montes Claros, Minas Gerais, Brazil. The number of gall morphotypes recorded (29) is low compared to the richness found by Coelho et al. (2009; 92 morphotypes), Goetz et al. (2018; 89 morphotypes) and Santos et al. (2011; 64 morphotypes) in other areas of Brazilian dry forest. This difference may have been due to the sampling method used, because the present study evaluated only one fragment of dry forest, while Coelho et al. (2009) sampled three, Goetz et al. (2018) sampled four, and Santos et al. (2011) sampled 11 areas. It is important to note that although all these studies were carried out in dry forests, these vegetations have 
Table 2. Morphological characterization of the gall morphotypes induced by arthropods in areas of deciduous seasonal forest of Parque da Sapucaia (Montes Claros, $M G$, Brazil).

\begin{tabular}{|c|c|c|c|c|c|c|}
\hline Host plant family/species & Organ & Shape & Color & Pilosity & Gall-inducing arthropod & Figure \\
\hline \multicolumn{7}{|l|}{ Anacardiaceae } \\
\hline Myracrodruon urundeuva Allemão & Leaf & Discoid & Brown & Glabrous & Cecidomyiidae & Fig. 2 (A) \\
\hline Schinopsis brasiliensis Engl. & Leaf & Amorphous & Green & Glabrous & Undetermined & Fig. 2 (B) \\
\hline \multicolumn{7}{|l|}{ Asteraceae } \\
\hline \multirow[t]{2}{*}{ Vernonanthura brasiliana (L.) H.Rob. } & Branch & Amorphous & Brown & Hairy & Cecidomyiidae & Fig. 2 (C) \\
\hline & Branch & Ellipsoid & Brown & Glabrous & Undetermined & Fig. 2 (D) \\
\hline \multicolumn{7}{|l|}{ Bignoniaceae } \\
\hline Bignoniaceae undetermined & Leaf & Discoid & Green & Glabrous & Cecidomyiidae & Fig. 2 (E) \\
\hline \multicolumn{7}{|l|}{ Cannabaceae } \\
\hline \multirow[t]{2}{*}{ Celtis brasiliensis (Gardner) Planch. } & Branch & Ellipsoid & Gray & Glabrous & Undetermined & Fig. 2 (F) \\
\hline & Leaf & Globoid & Green & Hairy & Cecidomyiidae & Fig. 2 (G) \\
\hline \multicolumn{7}{|l|}{ Combretaceae } \\
\hline Combretum leprosum Mart. & Leaf & Amorphous & Green & Glabrous & Undetermined & Fig. $2(\mathrm{H})$ \\
\hline Combretum duarteanum Cambess. & Leaf & Discoid & Brown & Glabrous & Undetermined & Fig. 2 (I) \\
\hline Terminalia phaeocarpa Eichler & Leaf & Globoid & Pink & Hairy & Cecidomyiidae & Fig. $2(J)$ \\
\hline \multicolumn{7}{|l|}{ Cucurbitaceae } \\
\hline Cucurbitaceae undetermined & Leaf & Amorphous & Green & Glabrous & Acari & Fig. $2(K)$ \\
\hline \multicolumn{7}{|l|}{ Fabaceae } \\
\hline Anadenanthera colubrina (Vell.) Brenan & Leaf & Conical & Brown & Glabrous & Cecidomyiidae & Fig. 2 (L) \\
\hline \multirow[t]{2}{*}{ Apuleia leiocarpa (Vogel) J.F.Macbr. } & Leaf & Discoid & Black & Glabrous & Cecidomyiidae & Fig. 2 (M) \\
\hline & Leaf & Amorphous & Brown & Glabrous & Cecidomyiidae & Fig. $2(\mathrm{~N})$ \\
\hline Bauhinia pulchella Benth. & Leaf & Globoid & Brown & Glabrous & Cecidomyiidae & Fig. $2(0)$ \\
\hline Bauhinia rufa (Bong.) Steud. & Leaf & Globoid & Green & Glabrous & Cecidomyiidae & Fig. 2 (P) \\
\hline \multirow[t]{3}{*}{ Dalbergia sp. } & Leaf & Discoid & Black & Glabrous & Cecidomyiidae & Fig. $3(\mathrm{~A})$ \\
\hline & Branch & Ellipsoid & Green & Glabrous & Undetermined & Fig. 3 (B) \\
\hline & Leaf & Globoid & Black & Glabrous & Undetermined & Fig. $3(C)$ \\
\hline \multirow[t]{2}{*}{ Fabaceae undetermined } & Leaf & Cylindrical & Green & Hairy & Cecidomyiidae & Fig. 3 (D) \\
\hline & Leaf & Amorphous & Green & Glabrous & Undetermined & - \\
\hline \multicolumn{7}{|l|}{ Loganiaceae } \\
\hline \multirow[t]{3}{*}{ Strychnos sp. } & Branch & Ellipsoid & Gray & Glabrous & Undetermined & Fig. 3 (E) \\
\hline & Leaf & Amorphous & Yellow & Glabrous & Acari & Fig. 3 (F) \\
\hline & Leaf & Discoid & Green & Glabrous & Acari & Fig. 3 (G) \\
\hline \multicolumn{7}{|l|}{ Opiliaceae } \\
\hline Agonandra brasiliensis Miers ex Benth. & Leaf & Amorphous & Yellow & Glabrous & Acari & Fig. $3(\mathrm{H})$ \\
\hline \multicolumn{7}{|l|}{ Sapindaceae } \\
\hline Serjania sp. & Leaf & Amorphous & Green & Glabrous & Acari & Fig. 3 (I) \\
\hline \multicolumn{7}{|l|}{ Vitaceae } \\
\hline Cissus sp. & Leaf & Cylindrical & Green & Glabrous & Psyllidae & Fig. $3(J)$ \\
\hline Undetermined family 1 & Leaf & Amorphous & Brown & Glabrous & Acari & Fig. $3(K)$ \\
\hline Undetermined family 2 & Leaf & Globoid & Green & Hairy & Undetermined & Fig. $3(\mathrm{~L})$ \\
\hline
\end{tabular}

great differences in their floristic composition, due to the influences of the biomes that compose the different regions of Brazil. In the south of the country, dry forests tend to be floristically influenced by Araucaria forests, in the Southeast by the Cerrado, and in the northeast by the Caatinga (Sanchez-Azofeifa et al., 2013). These differences in floristic composition may also influence the diversity of the gall-inducing fauna (Araújo et al., 2013). Considering the mean number of gall morphotypes per sampled area/fragment, the richness of gall-inducing species recorded in the present study is similar to or greater than that found in other studies (mean of 30, 22 and six morphotypes per area for Coelho et al., 2009, Goetz et al., 2018 and Santos et al., 2011, respectively).

Cecidomyiidae was the most important gall-inducing insect taxon, which corroborates the pattern observed in other studies carried out in different Neotropical floras (Altamirano et al., 2016; Fernandes et al., 2002; Maia \& Fernandes, 2004; Quintero et al., 2014; Rodrigues et al., 2014). Gall midges of the Cecidomyiidae family are the richest and most abundant gall-inducing insects in the Neotropical region (Gagné, 1994). Despite this, evidence indicates that the diversity of this group is underestimated due to the large number of species that remain unknown, and to the insufficient number of taxonomists working with the group (see Espírito-Santo \& Fernandes, 2007; Araújo, 2018; Hebert et al., 2016).

Another result of the present study was that Fabaceae hosted the largest number of gall morphotypes. Studies of entomogenous galls in Brazil recurrently identify Fabaceae as one of the most important host families in the country (Araújo et al., 2011b; Araújo et al., 2014; 


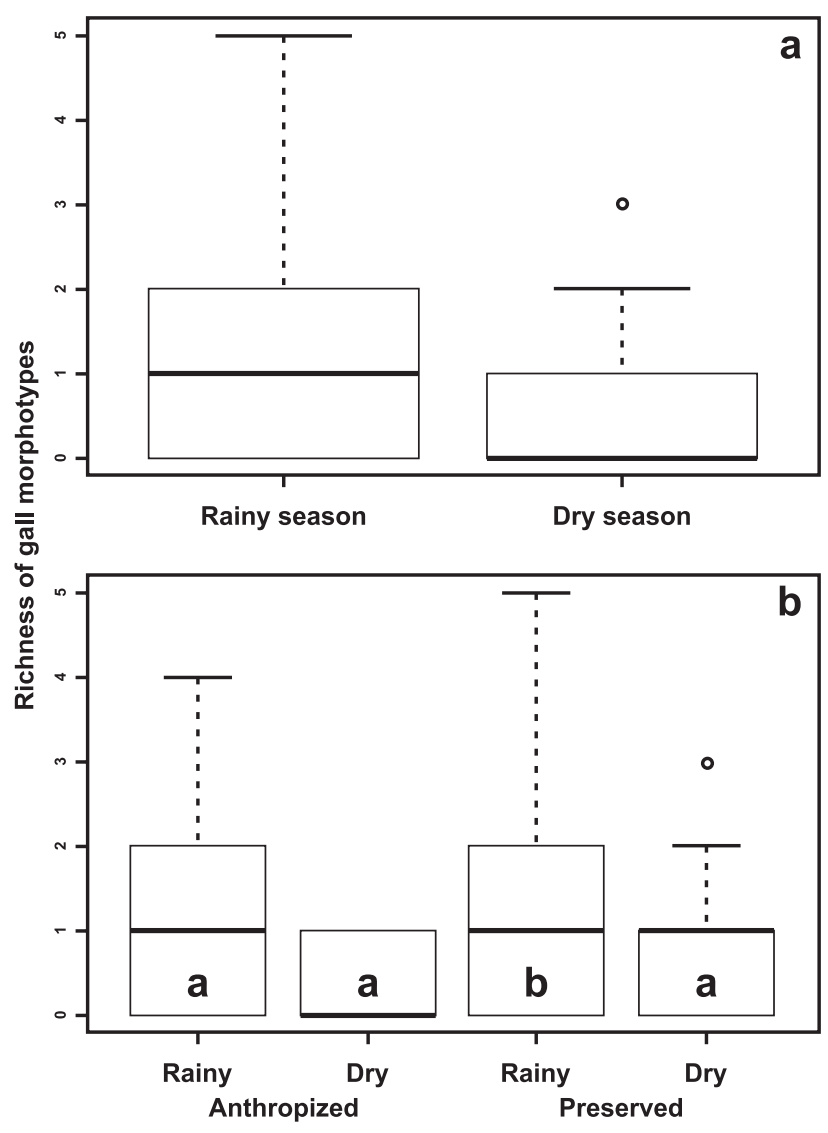

Figure 6. Comparison of the richness of gall morphotypes between different sampling seasons in the deciduous seasonal forest of Parque da Sapucaia (Montes Claros, MG, Brazil). (A) Comparison of the richness of gall morphotypes between the rainy and dry seasons. (B) Richness of gall morphotypes in the preserved and anthropized plots during the rainy and dry seasons.

Maia \& Fernandes, 2004; Silva et al., 2018). This pattern can be explained by the great diversity of this taxon in Brazil, with 2,848 species and 222 genera (Flora do Brasil, 2018). Studies have indicated that there is a positive correlation between the number of plant species in a given taxon and the number of gall-inducing species hosted by that taxon (Gonçalves-Alvim \& Fernandes, 2001; Fleck \& Fonseca, 2007).

Previous studies have indicated that the habitat's simplification due to anthropic pressures may increase the local concentration of host plants, favoring colonization by and increased populations of gall-inducing arthropods (Araújo \& Guilherme, 2012; Root, 1973). The present study found no significant differences between the number of gall morphotypes in the preserved plots and in the anthropized plots. As discussed earlier, the expectation was that anthropic environments would have a greater richness of gall-inducing arthropods since they tend to be more frequent in stressed environments (Fernandes et al., 1995; Price et al., 1998). The absence of a difference between preserved and anthropized areas may be due to structural factors of the vegetation, which varied widely between the studied plots.

The vegetation's structural complexity can be a good indicator of the nutritional quality and quantity of resources available to herbivorous insects (Cuevas-Reyes et al., 2003; Gonçalves-Alvim \& Fernandes, 2001). The results presented here show that both the mean height and density of the vegetation influence the richness of gall morphotypes, but in the opposite direction, with these structural factors negatively affecting gall richness. One possible explanation for these results is that the more complex vegetation areas feature greater vertical stratification of the arthropod galls (Paniagua et al., 2009). In this sense, denser and higher vegetation tends to have a higher occurrence of gall in the higher strata compared to the lower strata, which was the one sampled in this study. Other mechanisms responsible for these results may be related to the quality and concentration of resources in less complex environments. It was hypothesized that some host plants in less complex vegetation, due to less interspecific competition, can allocate more resources and thus be of better nutritional quality than plants in more complex environments. Thus, environments with less complex vegetation could have a greater diversity of arthropod galls than more structurally complex environments, but further studies are needed to test this hypothesis.

The results of the present study show that the gall-inducing arthropods' distribution is also influenced by seasonal patterns. Although the total number of gall morphotypes recorded during each field campaign did not differ between seasons, the mean number of gall morphotypes per plot was higher in the rainy season than in the dry season. This difference is probably due to the gall-inducing arthropods' adaptation to the phenological conditions of the host plant, since there is greater availability of water during the rainy season, and other factors that directly influence the development of the plant's leaves and branches (Araújo \& Santos, 2009; Figueirôa et al., 2004). This result corroborates the hypothesis that the appearance of the galls is synchronized with the period of active growth of the host plant (Cuevas-Reyes et al., 2004). Most gall-inducing arthropods occur in young plant tissues, particularly leaves (Bregonci et al., 2010; Fernandes \& Negreiros, 2006), which may explain the richness of gall morphotypes in humid periods, since that is the time when the foliar histogenesis of plants begins.

Previous studies have shown that different factors influence the richness of gall-inducing arthropods in Neotropical vegetation. Contrary to expectations, we did not find differences in the occurrence of galls between plots of preserved and anthropized environments, demonstrating that natural factors are more important for the distribution of these arthropods. In this sense, the present study revealed that the vegetation's structural components (e.g., height and density) and seasonal patterns, directly associated with the host plant species' phenological patterns, are fundamental elements for the occurrence of gall-inducing arthropods in these environments. Because our study was performed in an urban park, our results demonstrate the ecological importance of the maintenance of these spaces in urban and semi-urban regions for the conservation of the local diversity of gall-inducing arthropods. 


\section{ACKNOWLEDGMENTS}

We wish to thank Erik Wild for the English version's proofreading; professor Santos D'angelo Neto for the plant species' identification; colleagues of the Laboratory of Interactions, Ecology and Biodiversity - LIEB/UNIMONTES for their help during field sampling; Fundação de Amparo à Pesquisa de Minas Gerais (FAPEMIG) for the fellowship granted to the first author (PIBIC); Secretaria Municipal do Meio Ambiente de Montes Claros (SEMMA) for the collection license, and UNIMONTES for its logistical support.

\section{REFERENCES}

Almada, E.D. \& Fernandes, G.W. 2011. Insetos indutores de galhas em florestas de terra firme e em reflorestamentos com espécies nativas na Amazônia Oriental, Pará, Brasil. Boletim do Museu Paraense Emilio Goeldi, 6: 163-196.

Altamirano, A.; Valladares, G.; Kuzmanich, N. \& Salvo, A. 2016. Galling insects in a fragmented forest: incidence of habitat loss, edge effects and plant availability. Journal of Insect Conservation, 20: 119-127.

Alvares, C.A.; Stape, J.L.; Sentelhas, P.C.; De Moraes, J.L.G. \& Sparovek, G. 2013. Köppen's climate classification map for Brazil. Meteorologische Zeitschrift, 22: 711-728.

Araújo, A.P.A.; Paula, J.D.; Carneiro, M.A.A. \& Schoereder, J.H. 2006. Effects of host plant architecture on colonization by galling insects. Austral Ecology, 31: 343-348.

Araújo, W.S. \& Espírito-Santo Filho, K. 2012. Edge effect benefits galling insects in the Brazilian Amazon. Biodiversity and Conservation, 21: 2991-2997.

Araújo, W.S. \& Guilherme, F.A.G. 2012. Distribuição de insetos galhadores em diferentes formações vegetais e paisagens do Cerrado brasileiro. Bioscience Journal, 28: 810-819.

Araújo, W.S. \& Santos, B.B. 2009. Efeitos da sazonalidade e do tamanho da planta hospedeira na abundância de galhas de Cecidomyiidae (Diptera) em Piper arboreum (Piperaceae). Revista Brasileira de Entomologia, 53(2): 300-303.

Araújo, W.S.; Julião, G.R.; Ribeiro, B.A.; Silva, I.P.A. \& Santos, B.B. 2011a. Diversity of galling insects in Styrax pohlii (Styracaceae): edge effects and use as bioindicators. Revista de Biologia Tropical, 59: 1589-1597.

Araújo, W.S.; Santos, B.B. \& Gomes-Klein, V.L. 2011b. Insect galls from Serra dos Pireneus, G0, Brazil. Biota Neotropica, 11: 357-365.

Araújo, W.S.; Scareli-Santos, C.; Guilherme, F.A.G. \& Cuevas-Reyes, P. 2013. Comparing galling insect richness among Neotropical savannas: effects of plant richness, vegetation structure and super-host presence. Biodiversity and Conservation, 22: 1083-1094.

Araújo, W.S.; Sobral, F.L. \& Maracahipes, L. 2014. Insect galls of the Parque Nacional das Emas (Mineiros, G0, Brazil). Check List, 10: 1445-1451.

Araújo, W.S.D. 2018. 30 years of research on insect galls in Brazil: a scientometric review. Papéis Avulsos de Zoologia, 58: 1-11.

Bregonci, J.M.; Polycarpo, P.V. \& Maia, V.C. 2010. Insect galls of the Parque Estadual Paulo César Vinha (Guarapari, ES, Brazil). Biota Neotropical, 10: 265-274.

Brito, G.P.; Costa, E.C.; Carvalho-Fernandes, S.P. \& Santos-Silva, J. 2018. Richness of insect galls in Caatinga sites with different degrees of anthropogenic impact, Bahia State, Brazil. Iheringia, Série Zoologia, 108: e2018003. DOI

Coelho, M.S.; Almada, E.; Fernandes, G.E.; Carneiro, M.A.A.; Santos, R.M.; Quintino, A.V. \& Sanchez-Azofeifa, A. 2009. Gall inducing arthropods from a seasonally dry tropical forest in Serra do Cipó, Brazil. Revista Brasileira de Entomologia, 53: 404-414.

Cuevas-Reyes, P.; Quesada, M. \& Oyama, K. 2006. Abundance and leaf damage caused by gall-inducing insects in a Mexican tropical dry forest. Biotropica, 38: 107-115.

Cuevas-Reyes, P.; Quesada, M.; Hanson, P.; Dirzo, R. \& Oyama, K.E.N. 2004. Diversity of gall-inducing insects in a Mexican tropical dry forest: the importance of plant species richness, life-forms, host plant age and plant density. Journal of Ecology, 92: 707-716.

Cuevas-Reyes, P.; Siebe, C.; Martínez-Branchs, M. \& Oyama, K. 2003. Species richness of gall-forming insects in a tropical rain forest: correlations with plant diversity and soil fertility. Biodiversity and Conservation, 3: 411-422.

Espírito-Santo, M.M. \& Fernandes, G.W. 2007. How many species of gallinducing insects are there on earth, and where are there? Annals of the Entomological Society of America, 100: 95-99.

Fernandes, G.W. \& Negreiros, D. 2006. A comunidade de insetos galhadores da RPPN Fazenda Bulcão, Aimorés, Minas Gerais, Brasil. Lundiana, 7: $111-120$.

Fernandes, G.W.; Paula, A.S. \& Loyola, J.R. 1995. Distribuição diferencial de insetos galhadores entre habitats e seu possível uso como bioindicadores. Vida Silvestre Neotropical, 4(2): 133-139.

Fernandes, G.W.; Varela, 0.; Bucher, E.H.; Chani, J.M.; Echevarria, A.L.; EspíritoSanto, M.M.; Lima, J.; Negreiros, D. \& Toledo, C.S. 2002. Gall-forming insects on woody and herbaceous plant species of the semi-arid chaco forest, Argentina. Lundiana, 3: 61-66.

Fernandes, S.P.C.; Castelo-Branco, B.P.; Albuquerque, F.A.; Ferreira, A.L.N.; Branchs, A.B.; Braga, D.V.V. \& Almeida-Cortez, J. 2009. Galhas entomógenas em um fragmento urbano de Mata Atlântica no centro de endemismo de Pernambuco. Revista Brasileira de Biociências, 7: 240-244.

Figueirôa, J.M.; Barbosa, D.C.A. \& Simabukuro, E.A. 2004. Crescimento de plantas jovens de Myracrodruon urundeuva Allemão (Anacardiaceae) sob diferentes regimes hídricos. Acta Botanica Brasilica, 18: 573-580.

Filip, V.; Dirzo, R.; Mass, J.M. \& Sarukhan, J. 1995. Within and among year variation in the levels of herbivory on the foliage of trees from a Mexican tropical deciduous forest. Biotropica, 27: 78-86.

Fleck, T.\& Fonseca, C.R. 2007. Hipóteses sobre a riqueza de insetos galhadores: uma revisão considerando os níveis intra-específico, interespecífico e de comunidade. Neotropical Biology and Conservation, 2: 36-45.

Flora do Brasil. 2018. Flora do Brasil 2020 em construção. Jardim Botânico do Rio de Janeiro. Disponível em: http://floradobrasil.jbrj.gov.br. Acesso em: 06/09/2018.

Gagné, R.J. 1994. The gall midges of the Neotropical Region. Ithaca, Cornell University Press. 344p.

Goetz, A.P.M.; Luz, F.A.; Toma, T.S.P. \& Mendonça-Jr., M.S. 2018. Gall-inducing insects of deciduous and semideciduous forests in Rio Grande do Sul State, Brazil. Iheringia, Série Zoologia, 108: e2018015.

Gonçalves-Alvim, S. \& Fernandes, G.W. 2001. Biodiversity of galling insects: historical, community and habitat effects in four Neotropical savannas. Biodiversity and Conservation, 10: 79-98.

Hammer, Ø.; Harper D.A.T. \& Ryan P.D. 2001. PAST - Palaeontological Statistics. Palaeontologia Electronica, 4: 1-9.

Hebert, P.D.; Ratnasingham, S.; Zakharov, E.V.; Telfer, A.C.; LevesqueBeaudin, V.; Milton, M.A.; Pedersen, S.; Jannetta, P. \& de Waard, J.R. 2016. Counting animal species with DNA barcodes: Canadian insects. Philosophical Transactions of the Royal Society B: Biological Sciences, 371: 20150333. DOI

Isaias, R.M.D.S.; Carneiro, R.G.S.; Oliveira, D.C. \& Santos, J.C. 2013. Illustrated and annotated checklist of Brazilian gall morphotypes. Neotropical Entomology, 42: 230-239. 
Julião, G.R.; Venticinque, E.M. \& Fernandes, G.W. 2005. Richness and abundance of gall-forming insects in the Mamirauá Várzea, a flooded Amazonian forest. Uakari, 1: 39-42.

Maia, V. \& Fernandes, G. 2004. Insect galls from Serra de São José (Tiradentes, MG, Brazil). Brazilian Journal of Biology, 64: 423-445.

Mendonça, M.S.; Piccardi, H.M.F.; Jahnke, S.M. \& Dalbem, R. 2010. Galling Arthropod diversity in adjacent swamp forests and restinga vegetation in Rio Grande do Sul, Brazil. Neotropical Entomology, Londrina, 39: 513-518.

Paniagua, M.R.; Medianero, E. \& Lewis, 0.T. 2009. Structure and vertical stratification of plant galler-parasitoid food webs in two tropical forests. Ecological Entomology, 34: 310-320.

Price, P.W.; Fernandes G.W.; Lara, A.C.F.; Brawn, J.; Gerling, D.; Barrios, H.; Wright, M.G.; Ribeiro S.P. \& Rothcliff, N. 1998. Global patterns in local number of insect galling species. Journal of Biogeography, 25:581-591.

Quintero, C.; Garibaldi, L.A.; Grez, A.; Polidori, C. \& Nieves-Aldrey, J.L. 2014. Galls of the temperate forest of southern South America: Argentina and Chile. In: Fernandes, G.W. \& Santos, J.C. (Eds.). Neotropical insect galls. Netherlands, Springer. p. 429-463.

Rodrigues, A.R.; Maia, V.C. \& Couri, M.S. 2014. Insect galls of restinga areas of Ilha da Marambaia, Rio de Janeiro, Brazil. Revista Brasileira de Entomologia, 58: 173-197.

Root, R.B. 1973. Organization of plant-arthropod association in simple and diverse habitats: the fauna of collards (Brassica oleraceae). Ecological Monograph, 43: 95-124.
Sanchez-Azofeifa, A.; Powers, J.S.; Fernandes, G.W. \& Quesada, M. 2013. Tropical dry forests in the Americas: ecology, conservation, and management. CRC Press. $556 \mathrm{p}$.

Santos, J.C.; Almeida-Cortez, J.S. \& Fernandes, G.W. 2011. Richness of gallinducing insects in the tropical dry forest (Caatinga) of Pernambuco. Revista Brasileira de Entomologia, 55(1): 45-54.

Santos, R.M. \& Vieira, F.A. 2006. Similaridade Florística entre Formações de Mata Seca e Mata de Galeria no Parque Municipal da Sapucaia, Montes Claros, MG. Revista Científica de Engenharia Florestal, 7: 1-10.

Santos, R.M.; Vieira, F.A.; Gusmão, E. \& Nunes, Y.R.F. 2007. Florística e estrutura de uma floresta estacional decidual, no Parque Municipal da Sapucaia, Montes Claros (MG). Cerne, 13: 248-256.

Shorthouse, J.D. \& Rohfritsch, 0. 1992. Biology of insect induced Galls. New York, Oxford University. 285p.

Shorthouse, J.D.; Wool, D. \& Raman, A. 2005. Gall-inducing insects-Nature's most sophisticated herbivores. Basic and Applied Ecology, 6: 407-411.

Silva, E.C.; Santos, B.B.D. \& Araújo, W.S.D. 2018. Insect gall occurrence in savanna and forest remnant sites of Hidrolândia, G0, Brazil Central. Papéis Avulsos de Zoologia, 58: 1-14.

Stone, G.N. \& Schönrogge, K. 2003. The adaptive significance of insect gall morphology. Trends in Ecology and Evolution, 18: 512-522.

Toma, T.S.; Fernandes, G.W.; Souza, D.G.; Tabarelli, M. \& Santos, J.C. 2014. Galling insects as indicators of habitat quality. In: Fernandes, G.W. \& Santos, J.C. (Eds.). Neotropical Insect Galls. New York, Springer. p. 143-150. 